\title{
Paleozoic sedimentary record of the Xing-Meng Orogenic Belt, Inner Mongolia: Implications for the provenances and tectonic evolution of the Central Asian Orogenic Belt
}

\author{
LI DaPeng ${ }^{1,2^{*}}$, CHEN YueLong ${ }^{1}$, WANG Zhong ${ }^{3}$, LIN Yu ${ }^{1} \&$ ZHOU Jian ${ }^{4}$ \\ ${ }^{1}$ School of Earth Sciences and Resources, China University of Geosciences, Beijing 100083, China; \\ ${ }^{2}$ State Key Laboratory of Geological Processes and Mineral Resources, China University of Geosciences, Wuhan 430000, China; \\ ${ }^{3}$ Geological Survey Institute of Inner Mongolia, Hohhot 010000, China: \\ ${ }^{4}$ Institute of Geophysical and Geochemical Exploration, Langfang 102849, China
}

Received July 21, 2011; accepted October 12, 2011; published online November 26, 2011

\begin{abstract}
The Xing-Meng Orogenic Belt is the eastern extension of the Central Asian Orogenic Belt, which marks the boundary between the North China and Siberian blocks. Key information on the collision between these two blocks and the evolution of this orogenic belt at the end of the Paleozoic are preserved in the widely distributed Paleozoic sedimentary sequences. Petrographic studies of the clastic sedimentary rocks from the Ordovician to the Permian in this region have shown that the rocks are mainly greywackes and arkosic sandstones characterized by low maturity, poor sorting and a large number of lithic fragments. Provenances of Paleozoic sandstones are mainly newly accreted crustal materials. Nd model ages range from the Neoproterozoic to the Late Mesoproterozoic. These ages are very different from those of the North China Block, but the change of $\varepsilon_{\mathrm{Nd}}(t)$ (from the initial $\varepsilon_{\mathrm{Nd}}$ value) is similar to that of igneous rocks in the Xing-Meng Orogen. This result indicates that provenances of these Paleozoic sedimentary rocks mainly arise from the Xing-Meng Orogen itself. These clastic sedimentary rocks mainly consist of inputs of juvenile accreted crustal materials and limited recycled old crusts. Their provenance is controlled by the following three end members: a felsic basement, a partially melted mafic, and a mafic end member. From the point view of lithology, these three end members must have mixed in a ratio of 53:41:5 to form the average composition of the clastic sedimentary rocks. The depositional environment began to change from an arc to an orogen during the Permian, and therefore the collision was complete before the Triassic. This interpretation is consistent with the argument that the final collision time was at the end of the Permian or beginning of the Triassic.
\end{abstract}

clastic sedimentary rocks, Xing-Meng orogen, Nd isotopes, provenance, tectonic evolution

Citation: $\quad$ Li D P, Chen Y L, Wang Z, et al. Paleozoic sedimentary record of the Xing-Meng Orogenic Belt, Inner Mongolia: Implications for the provenances and tectonic evolution of the Central Asian Orogenic Belt. Chin Sci Bull, 2012, 57: 776-785, doi: 10.1007/s11434-011-4867-3

Terrigenous sedimentary rocks preserve important information on the composition, tectonic evolution, and growth history of the continental crust. The chemical compositions of clastic sedimentary rocks and relative abundance of different clast types have been used effectively to constrain detrital provenance [1-3], and to reconstruct the tectonic settings of depositional basins [4-7]. Detrital framework modes of sandstones can provide information about the tec-

*Corresponding author (email: ldpzhuanyong@163.com) tonic setting of a basin, its deposition, and the associated provenance [6,7]. Due to the limited mobility of rare earth elements during weathering, the $\mathrm{Sm}-\mathrm{Nd}$ isotopic systematics of detrital sediments provide a useful average of the Sm$\mathrm{Nd}$ isotopic systematics of the upper crust that has been exposed to weathering [8]. These data reveal that related inputs of juvenile materials derived from the mantle (compared with crustally evolved materials) were recycled from the crust [9-11]. Combined with geochemistry, Sm-Nd isotopes of detrital sedimentary rocks can help identify prove- 
nances dominated by different lithologies and crustal growth episodes [12-14].

The Xing-Meng Orogenic Belt is the eastern extension of the Central Asian Orogenic Belt (CAOB), and it marks the boundary between the North China Block (NCB) and the Siberian Block (SB) (Figure 1). Recent studies have shown that the history of the oceans between the North China and Siberian Blocks can be traced back to the Mesoproterozoic [15]. However, the position and timing of the final collision between the North China and Siberian Blocks have long been points of controversy [16-23].

In recent years, many sedimentary provenance studies have been carried out on various types of sedimentary rocks and metamorphic rocks with sedimentary protoliths in the Central Asian Orogenic Belts. These rocks include the pelitic schists of the Hulan Group in the southern part of the Songliao Block; the eastern section of the Xing-Meng Orogen [24]; the biotite-plagioclase paragneiss of the Xilinhot Metamorphic Complex in Inner Mongolia [25,26]; and the Early Paleozoic sedimentary rocks of the Chinese Altai Orogen [27]. Similar studies also have been carried out on the Zhaertai Group quartz sandstones [28] and the Wulashan khondalites [29] of the North China Block in Inner Mongolia. Phanerozoic strata are well-developed in the Xing-Meng Orogenic Belt in the central-eastern part of Inner Mongolia [30], and these strata preserve key information on plate collisions and the evolution of the orogenic belt. However, very few detailed geochemical studies have been carried out to investigate sedimentary provenance and the tectonothermal evolution of the provenance. In this study, clastic sedimentary rocks were collected from Ordovician to Permian age strata in the Xing-Meng Orogen for a whole-rock geochemical and $\mathrm{Sm}-\mathrm{Nd}$ isotopic study to determine the provenance characteristics and tectonic evolution of this orogen.

\section{Geological setting}

From south to north, the Xing-Meng Orogenic Belt can be subdivided into three main parts: the southern orogen, the Solonker suture zone, and the northern orogen (Figure 1). The major tectonic units of the southern orogen include the Bainaimiao arc and the Ordor Sum mélange. The MidOrdovician to Early Silurian Bainaimiao arc lies adjacent to the North China Block and consists of calc-alkaline tholeiitic basalts to minor felsic lavas and granitic plutons [31]. The Ondor Sum mélange lies to the north of the Bainaimiao arc and can be subdivided into an undeformed ophiolite, a folded island arc complex, and a thrusted mylonitic high-pressure subduction complex [22]. The SolonkerLinxi suture is marked by the Solonker-Linxi ophiolites of Permian-early Triassic age. This suture records the terminal evolution of the CAOB in Inner Mongolia [22]. The northern orogen includes the Xilinhot metamorphic complex, the Erdaojing subduction-accretion complex, and the Baolidao

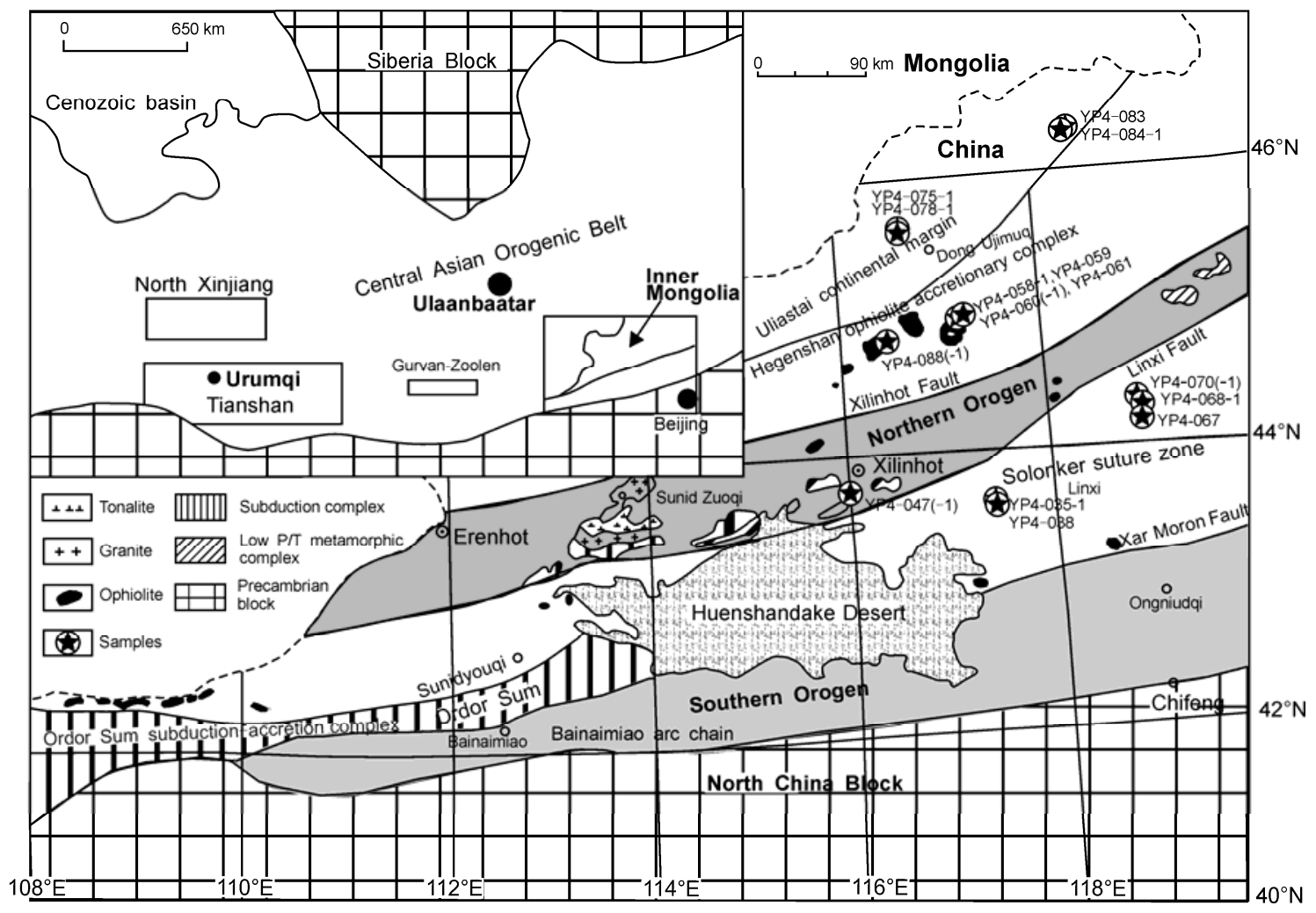

Figure 1 Geological map and distribution of samples (revised after Xiao et al. [22]). 
suite. The Xilinhot metamorphic complex consists of schist, paragneiss, orthogneiss, amphibolite, and ultramafic rocks [26] with metamorphic conditions up to the amphibolite facies for gneissic rocks [22,32]. Southwest of Xilinhot, the subduction-accretion complex extends for about $150 \mathrm{~km}$ from Erdaojing to Honger as a mélange in the middle of the northern orogen [33]. The Baolidao arc rocks were emplaced in the Late Carboniferous [26,34] and consist of a wide spectrum of rock types including gabbroic diorite, quartz diorite, tonalite, and granodiorite. The Hegenshan ophiolite accretionary complex, which has gabbros and mafic dikes that intruded at $298 \mathrm{Ma}$ [35], is located to the north of Xilinhot, and is connected to the Uliastai continental margin of the South Mongolian microcontinent.

\section{Sample petrography}

Eighteen samples of clastic sedimentary rocks were collected from the Ordovician to Permian strata in the XingMeng Orogen, which is in the central-eastern part of Inner Mongolia, (Figure 1, Table 1). They are black to grey in color, texturally immature, and poorly sorted (Figure 2). According to point counts ( $\sim 500$ points for each sample) performed on 9 representative thin sections, lithic fragments account for a large proportion $(32 \%-52 \%)$ of the material in all sections except for the thin sections of two Permian fine-grained sandstones, which contained only $4 \%$ and $6 \%$ lithic fragments, respectively. Quartz clasts, including monocrystalline quartz, polycrystalline quartz and chert, constitute $15 \%-60 \%$ of the rocks. Feldspars, which are mostly plagioclase, account for 5\%-38\%. Muscovite, biotite, calcite and opaque $\mathrm{Ti}-\mathrm{Fe}$ oxide were also observed in the thin sections as accessory minerals. The pore occluding phases (5\%-20\%) mainly consist of microcrystalline uralite and biotite with a small amount of silty sand.

\section{Analytical methods}

Whole-rock samples of clastic sedimentary rocks were crushed to $\sim 1-2 \mathrm{~cm}$, and approximately $100 \mathrm{~g}$ of the crushed fragments were further crushed to a 200-mesh powder in a corundum-based vessel. The major element compositions were analyzed at the Analytical Laboratory of the Beijing Research Institute of Uranium Geology by $\mathrm{X}$-ray fluorescence spectroscopy. The precision was better than $4 \%$, and the accuracy was better than $6 \%$. After sample digestion using a mixture of $\mathrm{HF}$ and $\mathrm{HNO}_{3}$ acid in a Teflon bomb, the trace elements and REEs were determined using an inductively coupled plasma mass spectrometer (ICPMS) (VG PQ Excell) at the Institute of Geology and Geophysics, Chinese Academy of Sciences. The accuracy was better than $8 \%$.

Four sandstone samples and three adjacent intercalated slate samples were analyzed for their $\mathrm{Sm}-\mathrm{Nd}$ isotopic compositions at the Institute of Geology and Geophysics at the Chinese Academy of Sciences. Nd isotopic data were obtained using the method described by Jahn et al. [36]. Mass analyses were performed using a 7-collector Finnigan MAT-262 in dynamic mode. The ${ }^{143} \mathrm{Nd} /{ }^{144} \mathrm{Nd}$ ratios were normalized against the value of ${ }^{146} \mathrm{Nd} /{ }^{144} \mathrm{Nd}=0.7219$. The ${ }^{143} \mathrm{Nd} /{ }^{144} \mathrm{Nd}$ ratios of the La Jolla and BCR-1 standard samples are $0.511937 \pm 10(2 \sigma)$ and $0.512594 \pm 10(2 \sigma)$, respectively.

Table 1 Localities and lithologies of clastic sedimentary rocks in the Xing-Meng Orogenic Belt in the central-eastern part of Inner Mongolia

\begin{tabular}{|c|c|c|c|}
\hline Sample No. & Series and formation name/lithology & Longitude (E) & Latitude $(\mathrm{N})$ \\
\hline YP4-035-1 & Lower Permian Yujiabeigou Fm./arkose & $117^{\circ} 26.972^{\prime}$ & $43^{\circ} 16.746^{\prime}$ \\
\hline YP4-038-1 & Lower Permian Zhesi Fm./graywacke & $117^{\circ} 24.857^{\prime}$ & $43^{\circ} 37.554^{\prime}$ \\
\hline YP4-058-1 & Carboniferous to Permian Benbatu Fm./fine-grained graywacke & $117^{\circ} 17.751^{\prime}$ & $45^{\circ} 01.699^{\prime}$ \\
\hline YP4-059 & Carboniferous to Permian Benbatu Fm./siltstone & $117^{\circ} 18.019^{\prime}$ & $45^{\circ} 00.401^{\prime}$ \\
\hline YP4-060 & Carboniferous to Permian Benbatu Fm./siltstone & $117^{\circ} 11.716^{\prime}$ & $45^{\circ} 00.052^{\prime}$ \\
\hline YP4-060-1 & Carboniferous to Permian Benbatu Fm./middle- to fine-grained graywacke & $117^{\circ} 11.716^{\prime}$ & $45^{\circ} 00.052^{\prime}$ \\
\hline YP4-061 & Carboniferous to Permian Benbatu Fm./fine-grained graywacke & $117^{\circ} 11.716^{\prime}$ & $45^{\circ} 00.052^{\prime}$ \\
\hline YP4-067 & Middle Permian Zhesi Fm./siltstone & $119^{\circ} 06.426^{\prime}$ & $44^{\circ} 15.709^{\prime}$ \\
\hline YP4-068-1 & Permian Dashizhai Fm./siltstone & $119^{\circ} 06.042^{\prime}$ & $44^{\circ} 17.911^{\prime}$ \\
\hline YP4-070 & Permian Shoushan Fm./fine-grained sandstone & $119^{\circ} 02.745^{\prime}$ & $44^{\circ} 20.690^{\prime}$ \\
\hline YP4-070-1 & Permian Shoushan Fm./siltstone & $119^{\circ} 02.745^{\prime}$ & $44^{\circ} 20.690^{\prime}$ \\
\hline YP4-076-1 & Devonian Niqiuhe Fm./middle- to coarse-grained arkose & $116^{\circ} 38.224^{\prime}$ & $45^{\circ} 38.105^{\prime}$ \\
\hline YP4-083 & Ordovician Duobaoshan Fm./middle- to coarse-grained graywacke & $118^{\circ} 22.872^{\prime}$ & $46^{\circ} 10.366^{\prime}$ \\
\hline YP4-084-1 & Silurian Woduhe Fm./middle- to coarse-grained arkose & $118^{\circ} 22.734^{\prime}$ & $46^{\circ} 09.981^{\prime}$ \\
\hline YP4-088 & Permian Gegenaobao Fm./graywacke & $116^{\circ} 26.388^{\prime}$ & $44^{\circ} 51.798^{\prime}$ \\
\hline YP4-088-1 & Permian Gegenaobao Fm./fine-grained graywacke & $116^{\circ} 26.388^{\prime}$ & $44^{\circ} 51.798^{\prime}$ \\
\hline
\end{tabular}



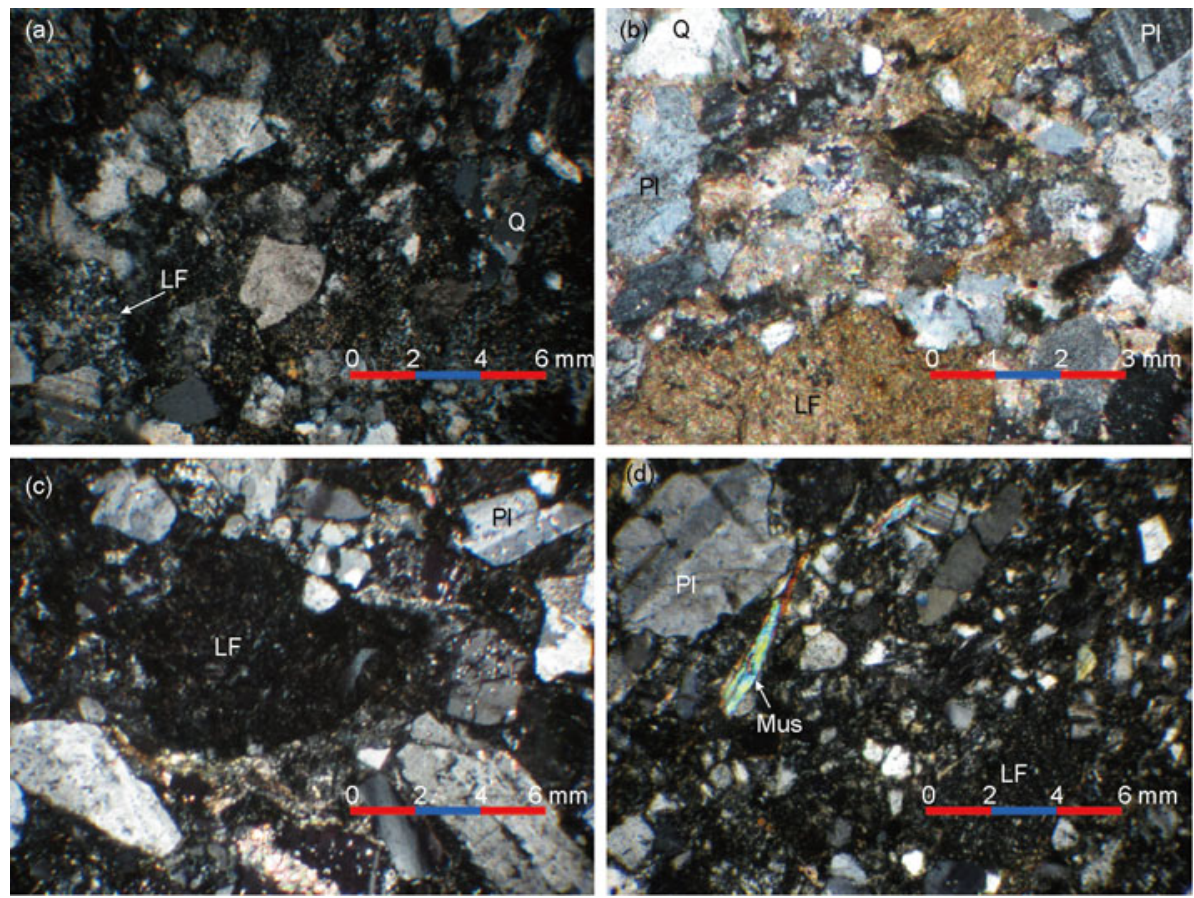

Figure 2 Photomicrographs of sandstones from the Xing-Meng Orogenic Belt showing their petrographic features. All photos were taken under cross-polarized light. These sandstones are characterized by low maturity, poor sorting and a great number of lithic fragments. (a) Carboniferous to Permian sandstone (YP4-058-1); (b) Carboniferous to Permian sandstone (YP4-060-1); (c) Devonian sandstone (YP4-078-1); (d) Silurian sandstone (YP4-080-1). Q, Quartz; Pl, plagioclase; Mus, muscovite; LF, lithic fragments.

\section{Results}

The whole rock major element compositions of the clastic sedimentary rocks from the Xing-Meng Orogenic Belt in the central-eastern part of Inner Mongolia are presented in Table 2. According to the diagram of Pettijohn et al. [37], the rocks are mainly greywackes and arkoses (Figure 3(a)). All samples are characterized by REE fractionation with low $(\mathrm{La} / \mathrm{Yb})_{\mathrm{N}}$ ratios (average 5.84). This average ratio is lower than that of the average upper crust (10.47 [38]) (Figure 3(b)), suggesting a relatively juvenile crustal contribution to the detrital sedimentary rocks from the Ordovician to Permian. The total rare earth element concentrations of the Ordovician, Devonian, Carboniferous and Permian strata range from $57 \mathrm{ppm}$ to $128 \mathrm{ppm}$ (Table 3 ). These values and the average of all of the samples are lower than the value for the upper crust (148 ppm [38]), indicating that a juvenile crustal contribution is predominant. The total rare earth element concentration of the Silurian is $168 \mathrm{ppm}$. This value is slightly higher than that for the upper crust, suggesting that the provenances during this period were dominated by recycled materials, or that the area experienced extreme magmatic differentiation. These rocks show variable negative $\mathrm{Eu}$ anomalies. The weakest negative $\mathrm{Eu}$ anomalies occur in the Devonian samples $\left(\mathrm{Eu} / \mathrm{Eu}^{*}=0.84\right)$, and the strongest anomaly is in the Carboniferous to Permian samples $\left(\mathrm{Eu} / \mathrm{Eu}^{*}=0.65\right)$ (Table 3).

The whole rock $\mathrm{Sm}-\mathrm{Nd}$ isotopic data for seven of the se- lected Paleozoic samples are listed in Table 4. These samples yield $\mathrm{Nd}$ model ages of 0.51 to $1.19 \mathrm{Ga}$.

\section{Discussion}

\subsection{Source area composition}

The texturally immature, poorly sorted clastic sedimentary rocks from the Xing-Meng Orogen have a great number of lithic fragments (Figure 2), which suggests that they were deposited close to eroded source rocks. The Nd model ages of rocks from the North China Block are Achaean in age (Figure 4(a)), which are clearly different from those of sedimentary rocks from the Xing-Meng Orogen. Therefore, inputs from $\mathrm{NCB}$, if there are any, cannot be dominant in these sedimentary rocks. All of the $\varepsilon_{\mathrm{Nd}}(t)$ values (initial $\varepsilon_{\mathrm{Nd}}$ values) of the sedimentary rocks plot in the igneous evolution area of the Xing-Meng Orogenic Belt. This igneous evolution area was determined from the $\mathrm{Nd}$ isotopes of 17 igneous rock samples and the $\mathrm{Nd}$ isotopes of igneous rocks from Hong et al. [41] in the Xing-Meng Orogenic Belt (Figure 4(b)). Except for one Silurian sample and one Permian sample, the $\varepsilon_{\mathrm{Nd}}(t)$ values of all of the clastic rocks are plotted in the main distribution of $\varepsilon_{\mathrm{Nd}}(t)$ values evolution area, indicating that these igneous rocks are the likely source of detritus for the clastic sediments.

These characteristics of the clastic sedimentary rocks, in combination with their $\mathrm{Nd}$ isotopes (Figure 4), suggest that 
Table 2 Concentrations of major (wt\%) and trace elements (ppm) in Phanerozoic clastic sedimentary rock

\begin{tabular}{|c|c|c|c|c|c|c|c|c|c|c|c|c|c|c|c|c|c|c|c|c|c|c|c|c|c|c|c|c|}
\hline Sample No. & $\mathrm{SiO}_{2}$ & $\mathrm{TiO}_{2}$ & $\mathrm{Al}_{2} \mathrm{O}_{3}$ & $\mathrm{Fe}_{2} \mathrm{O}_{3}$ & $\mathrm{MnO}$ & $\mathrm{MgO}$ & $\mathrm{CaO}$ & $\mathrm{Na}_{2} \mathrm{O}$ & $\mathrm{K}_{2} \mathrm{O}$ & $\mathrm{P}_{2} \mathrm{O}_{5}$ & LOI & $\mathrm{Sc}$ & $\mathrm{Zr}$ & Th & $\mathrm{La}$ & $\mathrm{Ce}$ & $\operatorname{Pr}$ & $\mathrm{Nd}$ & $\mathrm{Sm}$ & $\mathrm{Eu}$ & $\mathrm{Gd}$ & $\mathrm{Tb}$ & Dy & Ho & $\mathrm{Er}$ & $\mathrm{Tm}$ & $\mathrm{Yb}$ & $\mathrm{Lu}$ \\
\hline D.L.* & & & & & & & & & & & & 0.04 & 0.01 & 0.01 & 0.04 & 0.07 & 0.02 & 0.03 & 0.02 & 0.03 & 0.02 & 0.02 & 0.03 & 0.02 & 0.02 & 0.02 & 0.02 & 20.02 \\
\hline YP4-035-1 & 64.9 & 0.8 & 16.4 & 5.2 & 0.1 & 1.4 & 0.7 & 1.1 & 3.3 & 0.2 & 5.9 & 11 & 228 & 14 & 40 & 83.3 & 9.5 & 37 & 7 & 1.2 & 6 & 1 & 5.5 & 1.2 & 3.2 & 0.5 & 3.2 & 0.5 \\
\hline YP4-038-1 & 73.3 & 0.6 & 13.5 & 4.3 & 0.1 & 0.9 & 1.4 & 2 & 1.8 & 0.1 & 2.1 & 9 & 191 & 9.7 & 45 & 85.9 & 11 & 41 & 8.1 & 1.5 & 6.9 & 1 & 6 & 1.2 & 3.4 & 0.5 & 3.4 & 0.5 \\
\hline YP4-047-1 & 70.4 & 0.5 & 14.1 & 4 & 0 & 1.1 & 0.7 & 1.8 & 2.6 & 0.1 & 4.4 & 7 & 198 & 7.2 & 20 & 41.9 & 5.5 & 20 & 4.2 & 0.9 & 3.5 & 0.6 & 3.5 & 0.8 & 2.2 & 0.3 & 2.3 & 0.4 \\
\hline YP4-058-1 & 67.4 & 0.6 & 14.3 & 4.8 & 0.1 & 1.9 & 3.5 & 3.5 & 2.2 & 0.1 & 1.6 & 6 & 156 & 5.3 & 14 & 30.2 & 4.2 & 16 & 3.9 & 1 & 3 & 0.5 & 3.2 & 0.7 & 2.1 & 0.3 & 2.2 & 0.4 \\
\hline YP4-059 & 67.1 & 0.8 & 14.5 & 5.8 & 0 & 1.6 & 0.9 & 1.4 & 2.3 & 0.1 & 5.2 & 11 & 256 & 11 & 33 & 66.9 & 8.8 & 34 & 8.2 & 1.2 & 7.2 & 1.2 & 7.4 & 1.6 & 4.4 & 0.7 & 4.4 & 0.7 \\
\hline YP4-060-1 & 68 & 0.8 & 13.6 & 6.6 & 0.1 & 2.3 & 1 & 3.3 & 0.9 & 0.2 & 3.2 & 9 & 157 & 4.4 & 18 & 40.6 & 4.8 & 18 & 4.2 & 1.1 & 3.8 & 0.6 & 3.7 & 0.8 & 2.1 & 0.3 & 2.1 & 0.3 \\
\hline YP4-061 & 51.1 & 0.5 & 12.7 & 3.9 & 0.4 & 1.3 & 12.8 & 4.9 & 1.4 & 0.1 & 11 & 10 & 138 & 4.8 & 18 & 34.9 & 4.2 & 16 & 3.4 & 0.9 & 3.3 & 0.5 & 3.2 & 0.7 & 2 & 0.3 & 2.2 & 0.3 \\
\hline YP4-067 & 68.8 & 0.5 & 13.4 & 3.5 & 0.1 & 2.1 & 4.7 & 3.5 & 2.2 & 0.1 & 1 & 12 & 225 & 8.3 & 29 & 56.4 & 6.7 & 24 & 5.1 & 1.1 & 4.5 & 0.7 & 4.1 & 0.9 & 2.5 & 0.4 & 2.5 & 0.4 \\
\hline YP4-068-1 & 54.8 & 0.6 & 19.1 & 7.9 & 0.2 & 3.9 & 9 & 3.3 & 0.2 & 0.3 & 0.7 & 28 & 48 & 1.3 & 7.7 & 18 & 2.4 & 11 & 3 & 0.8 & 3.3 & 0.6 & 3.8 & 0.8 & 2.2 & 0.3 & 2.2 & 0.3 \\
\hline YP4-070 & 73.2 & 0.6 & 14.2 & 3.1 & 0 & 0.5 & 0.4 & 2.4 & 2.4 & 0.2 & 2.6 & 11 & 198 & 9.7 & 34 & 66.4 & 8.6 & 29 & 5.7 & 1.2 & 5.2 & 0.8 & 4.9 & 1 & 2.9 & 0.4 & 2.8 & 0.4 \\
\hline YP4-070-1 & 71.1 & 0.7 & 15.5 & 3.6 & 0.1 & 0.5 & 0.5 & 1.9 & 3 & 0.2 & 2.7 & 9 & 209 & 11 & 32 & 67.9 & 8.4 & 31 & 6.2 & 1.2 & 6.1 & 0.9 & 5.6 & 1.2 & 3.2 & 0.5 & 3.2 & 0.5 \\
\hline YP4-075-1 & 70.9 & 0.6 & 11.7 & 4.6 & 0.1 & 1.5 & 1.9 & 1.9 & 3.3 & 0.1 & 3.3 & 16 & 115 & 5.1 & 10 & 22.6 & 2.9 & 11 & 2.9 & 0.8 & 2.4 & 0.4 & 2.3 & 0.5 & 1.3 & 0.2 & 1.4 & 0.2 \\
\hline YP4-083 & 63.6 & 0.6 & 15.2 & 8.4 & 0.1 & 2 & 0.5 & 3.5 & 1.2 & 0.2 & 4.3 & 12 & 120 & 3.8 & 9.7 & 22.3 & 2.7 & 10 & 2.4 & 0.6 & 2.1 & 0.4 & 2.2 & 0.5 & 1.4 & 0.2 & 1.5 & 0.2 \\
\hline YP4-084-1 & 61.9 & 1 & 16.5 & 7.3 & 0.1 & 2.7 & 0.6 & 1.3 & 2.5 & 0.2 & 5.7 & 22 & 183 & 8.3 & 33 & 67.7 & 8.4 & 31 & 6.3 & 1.5 & 5.7 & 0.9 & 5.3 & 1.1 & 3 & 0.5 & 3.1 & 0.5 \\
\hline YP4-088 & 65.8 & 0.5 & 11.8 & 6.4 & 0.1 & 2.2 & 3.6 & 4.8 & 0.1 & 0.1 & 4.5 & 15 & 54 & 0.9 & 6.4 & 15.2 & 2.1 & 9.8 & 3 & 0.9 & 3.6 & 0.6 & 4.3 & 0.9 & 2.8 & 0.4 & 2.9 & 0.5 \\
\hline YP4-088-1 & 63.7 & 0.5 & 11.9 & 5.1 & 0.2 & 1.7 & 5.2 & 6 & 0.1 & 0.1 & 5.2 & 13 & 122 & 3.1 & 14 & 32.1 & 4.4 & 18 & 4.6 & 1.1 & 4.6 & 0.9 & 5.8 & 1.3 & 3.8 & 0.6 & 4.1 & 0.7 \\
\hline
\end{tabular}

*D.L. means detective limitations $(\mathrm{ng} / \mathrm{mL})$ for trace elements in solution.
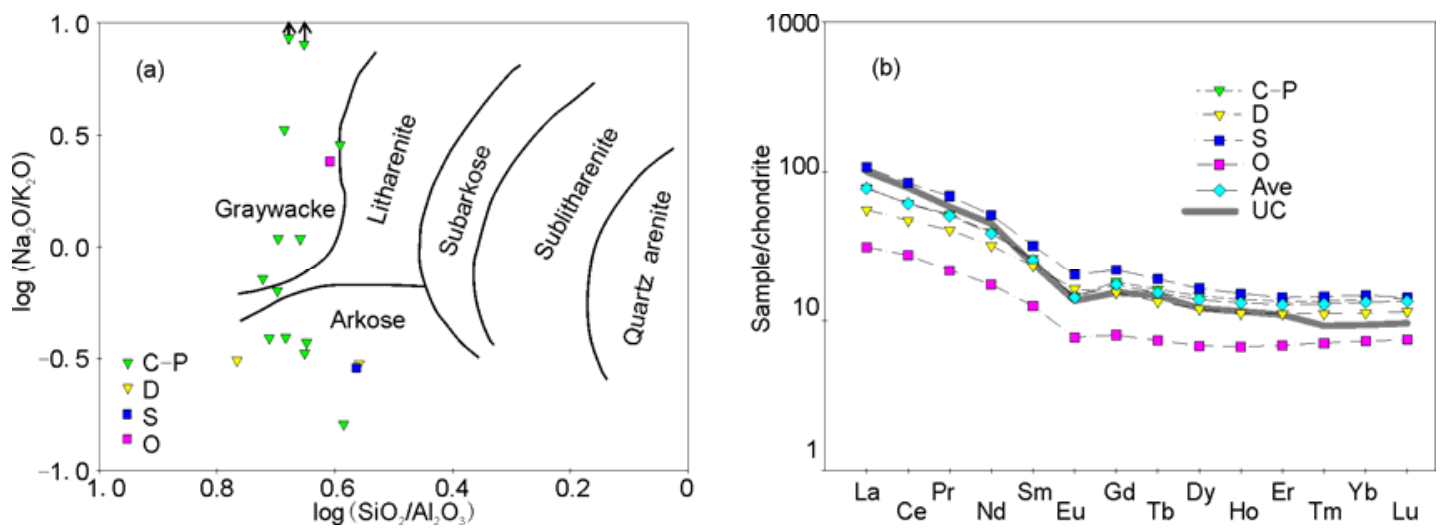

Figure 3 Geochemical characteristics of clastic sedimentary rocks of the Xing-Meng Orogenic Belt. (a) Chemical classification based on the log $\left(\mathrm{SiO}_{2} /\right.$ $\left.\mathrm{Al}_{2} \mathrm{O}_{3}\right)$ vs. $\log \left(\mathrm{Na}_{2} \mathrm{O} / \mathrm{K}_{2} \mathrm{O}\right)$ diagram of Pettijohn et al. [37]; (b) chondrite-normalized REE pattern of sedimentary rocks with different depositional ages. The chondrite normalizing values are adopted from [39], and the Upper Crust values are adopted from [38].

Paleozoic igneous and metamorphic rocks in the XingMeng Orogenic Belt were the direct source of detritus for the clastic sedimentary rocks. Thus, the $\mathrm{Na}_{2} \mathrm{O} / \mathrm{K}_{2} \mathrm{O}$ ratios of the clastic sedimentary rocks and the pre-Mesozoic igneous and metamorphic rocks from the Xing-Meng Orogenic Belt in the eastern to central part of Inner Mongolia were plotted together against their total rare earth element concentrations (Figure 5(a)) to further constrain the source area composition [42].

The sedimentary rocks all overlapped in a triangular area formed by pre-Mesozoic igneous and metamorphic rocks from the Xing-Meng Orogenic Belt, which indicates the chemical compositions of the latter rocks controlled the composition of the former (Figure 5(a)). The three vertices of the triangle represent three different end member types.
One end member has a high $\mathrm{Na}_{2} \mathrm{O} / \mathrm{K}_{2} \mathrm{O}$ ratio and a low total rare earth element concentration (labeled MF). This end member comprises ultramafic rocks (peridotite xenolith) and, thus, should represent a mafic end member. The other two end members are complex. The MELTs algorithm [43-45] was used to calculate the changes in the $\mathrm{Na}_{2} \mathrm{O} / \mathrm{K}_{2} \mathrm{O}$ ratios and total rare earth element concentrations during magmatic processes, based on chemical composition of the peridotite xenolith to define the representation of these two end members. Batch melting of the peridotite was assumed to occur at the Moho, and the magma segregated from the residual phases when the melt fraction accumulated to over $30 \mathrm{wt} \%$ [46]. The magma was then assumed to have been transported to the upper crust $(\sim 8 \mathrm{~km})$ and evolved there via crystallization [47]. 
Table 3 REE concentrations (ppm) of clastic sedimentary rocks of different periods from the Xing-Meng Orogen

\begin{tabular}{llllllll}
\hline Element & $\mathrm{CI}^{\mathrm{a})}$ & $\mathrm{UC}^{\mathrm{b})}$ & $\mathrm{C}-\mathrm{P}$ & $\mathrm{D}$ & $\mathrm{S}$ & $\mathrm{O}$ & $\mathrm{Ave}^{\mathrm{c})}$ \\
\hline $\mathrm{La}$ & 0.31 & 31 & 24.1 & 17.3 & 33.1 & 9.7 & 24 \\
$\mathrm{Ce}$ & 0.808 & 63 & 49.5 & 38.2 & 67.7 & 22.3 & 49.3 \\
$\mathrm{Pr}$ & 0.122 & 7.1 & 6.31 & 4.98 & 8.39 & 2.66 & 6.2 \\
$\mathrm{Nd}$ & 0.6 & 27 & 23.7 & 19.2 & 30.8 & 10.5 & 23.1 \\
$\mathrm{Sm}$ & 0.195 & 4.7 & 5.14 & 4.56 & 6.25 & 2.44 & 4.99 \\
$\mathrm{Eu}$ & 0.0735 & 1 & 1.07 & 1.2 & 1.49 & 0.57 & 1.05 \\
$\mathrm{Gd}$ & 0.259 & 4 & 4.73 & 4 & 5.68 & 2.08 & 4.52 \\
$\mathrm{~Tb}$ & 0.0474 & 0.7 & 0.77 & 0.64 & 0.9 & 0.35 & 0.73 \\
$\mathrm{Dy}$ & 0.322 & 3.9 & 4.7 & 3.86 & 5.29 & 2.19 & 4.46 \\
$\mathrm{Ho}$ & 0.0718 & 0.83 & 0.99 & 0.81 & 1.09 & 0.48 & 0.94 \\
$\mathrm{Er}$ & 0.21 & 2.3 & 2.82 & 2.33 & 2.99 & 1.44 & 2.69 \\
$\mathrm{Tm}$ & 0.0324 & 0.3 & 0.44 & 0.36 & 0.47 & 0.23 & 0.42 \\
$\mathrm{Yb}$ & 0.209 & 1.96 & 2.9 & 2.35 & 3.09 & 1.53 & 2.78 \\
$\mathrm{Lu}$ & 0.0322 & 0.31 & 0.45 & 0.37 & 0.46 & 0.24 & 0.44 \\
$\mathrm{Eu} / \mathrm{Eu}^{*}$ & & 0.69 & 0.65 & 0.84 & 0.75 & 0.75 & 0.67 \\
$\mathrm{SREE}$ & & 148 & 128 & 100 & 168 & 57 & 126 \\
\hline
\end{tabular}

Mean values of the rocks with different periods from the Xing-Meng Orogenic Belt are calculated from data in Table 2. a) CI data are from [39]; b) UC signifies Upper Crust; these data are from [38]; c) Ave means average values of all analyzed samples. d) $\Sigma$ REE represents total REE concentrations.
Changes in $\mathrm{Na}_{2} \mathrm{O} / \mathrm{K}_{2} \mathrm{O}$ ratios and total rare earth element concentrations during these magmatic processes are shown in Figure 5(a). In the last stage, when the residual magma fraction decreased to $\sim 75 \%$, the $\mathrm{Na}_{2} \mathrm{O} / \mathrm{K}_{2} \mathrm{O}$ ratio reached $2.6 \%$ of the initial $\mathrm{Na}_{2} \mathrm{O} / \mathrm{K}_{2} \mathrm{O}$ ratio of the peridotite xenolith, and the total rare earth element concentration and $\mathrm{Nd}$ concentration were enriched 8.65 and 8.34 times, respectively. Then, the information in Figure 5(a), suggests that the mafic rocks with low total REE concentrations and different $\mathrm{Na}_{2} \mathrm{O} / \mathrm{K}_{2} \mathrm{O}$ ratios probably partially melted from different mafic or ultramafic rocks. Thus, the end member with a low $\mathrm{Na}_{2} \mathrm{O} / \mathrm{K}_{2} \mathrm{O}$ ratio and a low total REE concentration represents mafic rocks that partially melted. The calculated residual magma at the final stage is felsic, suggesting that the end member with a low $\mathrm{Na}_{2} \mathrm{O} / \mathrm{K}_{2} \mathrm{O}$ ratio and a high total REE concentration likely represents felsic rocks, such as the biotite plagioclase metaconglomerate shown in Figure 5(a). The contribution of the felsic end member, the mafic end member and the partially melted mafic end member must have been 53:41:5 to form the average chemical composition of these sedimentary rocks. Ultramafic rocks provided less detrital input to these sedimentary rocks. This interpretation

Table 4 Sm-Nd isotopic compositions of sandstone and interbedded slate from the Xing-Meng Orogen ${ }^{\text {a) }}$

\begin{tabular}{llccccccccc}
\hline Sample No. & Lithology & Deposition age $(\mathrm{Ma})$ & $\mathrm{Sm}(\mathrm{ppm})$ & $\mathrm{Nd}(\mathrm{ppm})$ & ${ }^{147} \mathrm{Sm} /{ }^{144} \mathrm{Nd}$ & ${ }^{143} \mathrm{Nd} /{ }^{144} \mathrm{Nd}$ & $2 \sigma$ & $f_{\mathrm{Sm} / \mathrm{Nd}}$ & $T_{\mathrm{DM}}(\mathrm{Ga})$ & $T_{\mathrm{DM} 2}(\mathrm{Ga})$ \\
\hline YP4-035 & slate & 270 & 7.1231 & 36.3858 & 0.118419 & 0.512480 & 0.000012 & -0.40 & 1.07 & 1.07 \\
YP4-058-1 & sandstone & 260 & 2.4420 & 10.7112 & 0.137912 & 0.512799 & 0.000012 & -0.30 & 0.71 & 0.56 \\
YP4-060-1 & sandstone & 300 & 1.6044 & 9.5957 & 0.101140 & 0.512508 & 0.000013 & -0.49 & 0.87 & 1.02 \\
YP4-061 & sandstone & 254 & 3.3044 & 15.7842 & 0.126563 & 0.512761 & 0.000013 & -0.36 & 0.68 & 0.62 \\
YP4-076-1 & slate & 360 & 7.0749 & 26.8142 & 0.159603 & 0.512828 & 0.000005 & -0.19 & 0.91 & 0.51 \\
YP4-084 & slate & 420 & 6.5699 & 33.1684 & 0.119751 & 0.512416 & 0.000019 & -0.39 & 1.19 & 1.17 \\
YP4-083-1 & slate & 445 & 3.6849 & 15.6660 & 0.142202 & 0.512681 & 0.000015 & -0.28 & 1.00 & 0.75 \\
\hline
\end{tabular}

a) Nd model ages ( $T_{\mathrm{DM}}$ and $T_{\mathrm{DM} 2}$ ) were calculated according to $\mathrm{Wu}$ et al. [40].
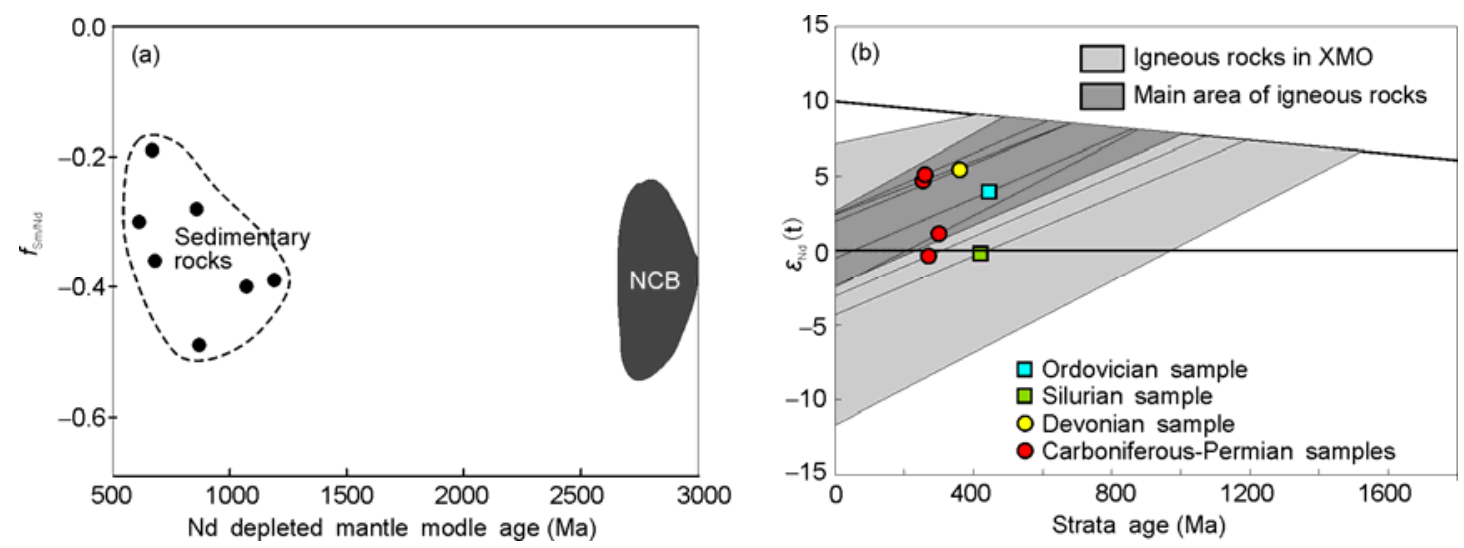

Figure $4 \mathrm{Nd}$ isotopic composition that is characteristic of clastic rocks from the Xing-Meng Orogenic Belt. (a) Nd depleted mantle model ages of clastic sedimentary rocks showing that the Nd composition of these sedimentary rocks in the Xing-Meng Orogenic Belt is different from that of the North China Block (NCB). (b) The $\varepsilon_{\mathrm{Nd}}$ evolution of clastic sedimentary rocks with time. The provenances are closely related to the igneous rocks in the Xing-Meng Orogenic Belt itself. The Nd model ages of North China are from [27], and the $\varepsilon_{\mathrm{Nd}}$ values of the igneous rocks in the Xing-Meng Orogenic Belt are partly from [41]. 

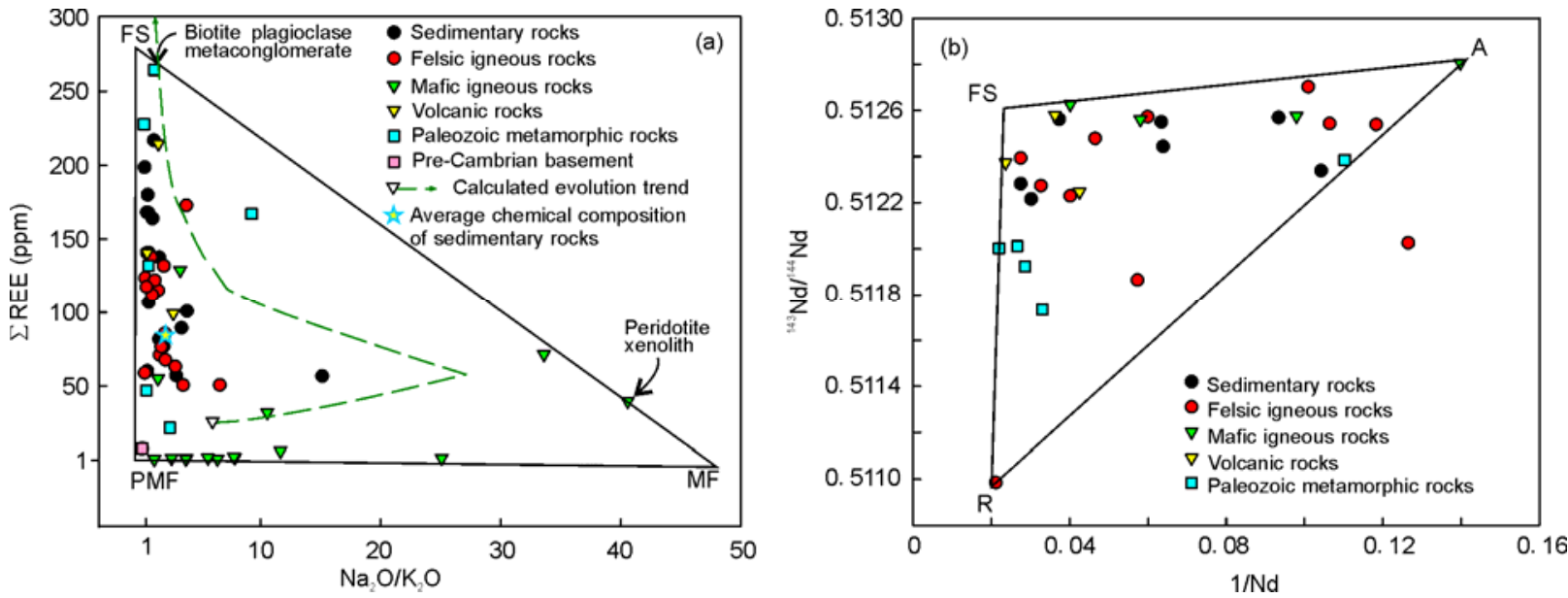

Figure 5 Provenance features of clastic sedimentary rocks in the Xing-Meng Orogenic Belt [42]. (a) Plot of the total $\mathrm{REE}$ concentration vs. the $\mathrm{Na}_{2} \mathrm{O} / \mathrm{K}_{2} \mathrm{O}$ ratios. End members: MF, mafic end member; PMF, partial melted mafic end member; FS, felsic end member. The green dashed line is the calculated evolution trend of the total REE concentration vs. the $\mathrm{Na}_{2} \mathrm{O} / \mathrm{K}_{2} \mathrm{O}$ ratio of magma generated from the peridotite xenolith during batch melting at the Moho to $\sim 30$ $\mathrm{wt} \%$, and crystallization in the upper crust ( $\sim 8 \mathrm{~km}$ in depth) until $\sim 75 \%$ of the melt was left. The evolutionary trend of the total REE concentration vs. the $\mathrm{Na}_{2} \mathrm{O} / \mathrm{K}_{2} \mathrm{O}$ ratio of the calculated magma is close to some mafic and felsic igneous rocks, indicating that these rocks could have experienced the magmatic processes mentioned above. The contribution of the felsic, mafic, and partially melted mafic end member should have been 53:5:41 to form the average chemical composition of these sedimentary rocks (the pentagram in Figure 5(a)). (b) Plot of the ${ }^{143} \mathrm{Nd} /{ }^{144} \mathrm{Nd}$ ratios vs. Nd concentrations. End members: A, accreted end member; R, recycled end member; FS, felsic end member.

is consistent with geological evidence in this region because few of the rock components (e.g. peridotite) represent the mafic end member.

The isotopic ratios and reciprocal values of the same element should be linearly distributed among the two end member mixtures [48]. According to the MELTs calculation, during partial melting of the mafic rocks and magma crystallization, the $\mathrm{Nd}$ concentration became enriched. The $\mathrm{Nd}$ isotopic data from 31 different rock types are plotted against their Nd concentrations in Figure 5(b). The result shows that these sedimentary rocks in the Xing-Meng Orogenic Belt should be interpreted as mixtures of the following three end members: an accreted end member (A) represented by mafic or ultramafic intrusions with a high ${ }^{143} \mathrm{Nd} /{ }^{144} \mathrm{Nd}$ ratio and a low Nd concentration; a recycled end member $(\mathrm{R})$ represented by acidic to intermediate intrusions remelted from old crust with a low ${ }^{143} \mathrm{Nd} /{ }^{144} \mathrm{Nd}$ ratio and a high $\mathrm{Nd}$ concentration; and a felsic end member (FS) with a high ${ }^{143} \mathrm{Nd} /{ }^{144} \mathrm{Nd}$ ratio and a high $\mathrm{Nd}$ concentration. The similarity of the $\mathrm{Nd}$ isotopic compositions of FS and A indicates that the inputs are mainly composed of juvenile accreted crustal materials and a few recycled old crustal components (Figure 5(b)).

\subsection{Implication for regional tectonics}

Nine sandstones from different periods are plotted in the Q-F-L diagram (Figure 6). The Silurian and Devonian sandstones are located in the area that represents a transitional arc. The Carboniferous to Permian sandstones are plotted in the transitional or dissected arc. The Permian sandstones were partly in a recycled orogen, which should indicate that they formed in a forearc region [49], according to the

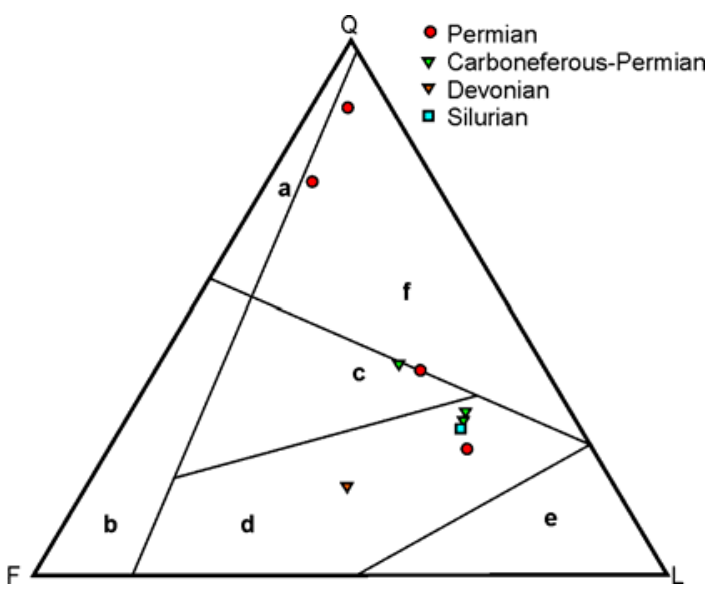

Figure 6 Ternary plots of modal sandstone grain compositions for clastic sedimentary rocks from the Xing-Meng Orogenic Belt [7]. End members: $\mathrm{Q}$, total quartz; F, total feldspars; L, total lithic fragments. Fields: a, craton interior; b, basement uplift; c, dissected arc; d, transitional arc; e, undissected arc; f, recycled orogen.

regional tectonic evolution [22,23,50]. The distribution of sandstones from different periods indicates that the environment of the deposition was a magmatic arc from the $\mathrm{Si}$ lurian to the Carboniferous. The depositional environment began to change from an arc to an orogen during the Permian. This interpretation is consistent with results of the detrital zircon $\mathrm{U}-\mathrm{Pb}$ ages and $\mathrm{Hf}$ isotopes of sedimentary rocks from Silurian to Permian samples [50]. The sandstones of the Xing-Meng Orogenic Belt have a greater percentage of lithic fragments. This result also indicates presence of arc accretion deposits.

The geochemical characteristics of sedimentary rocks also have been used to determine their tectonic setting [4,5,51]. 

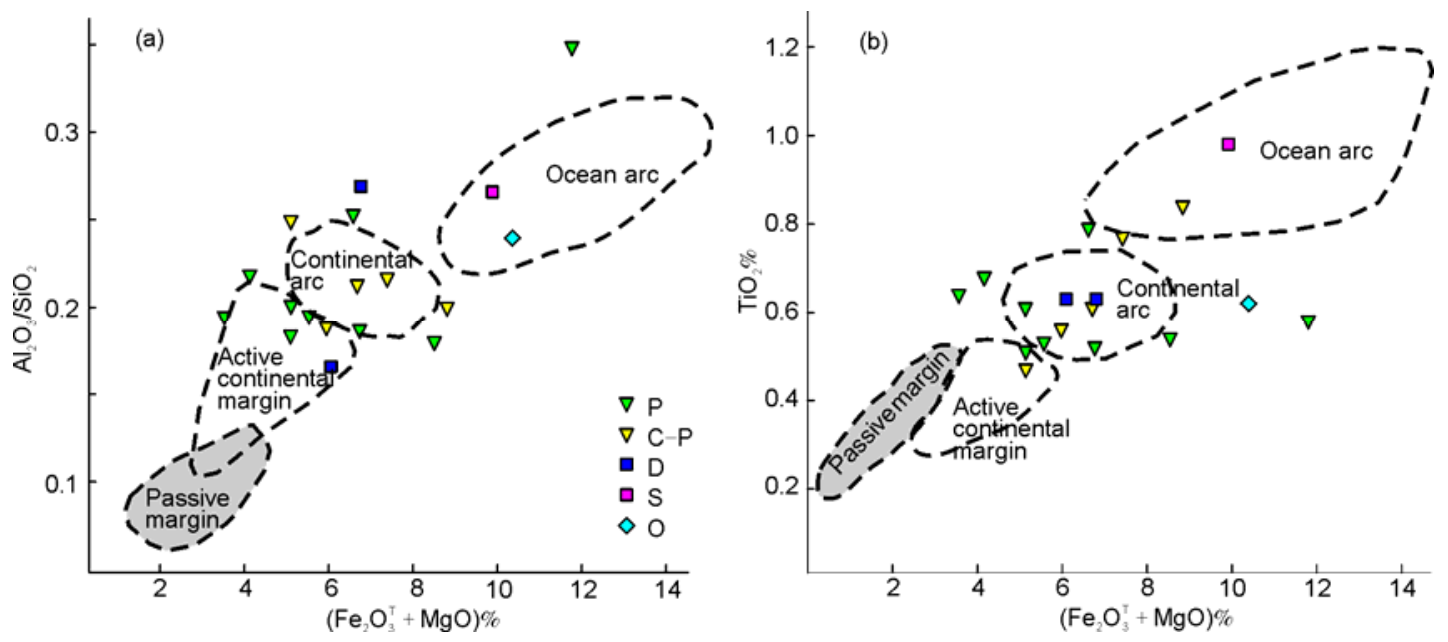

Figure 7 Discrimination diagrams of sedimentary environments using major element compositions for clastic sedimentary rocks in the Xing-Meng Orogenic Belt [4]. (a) $\mathrm{Fe}_{2} \mathrm{O}_{3}{ }^{\mathrm{T}}+\mathrm{MgO}$ vs. $\mathrm{Al}_{2} \mathrm{O}_{3}$; (b) $\mathrm{Fe}_{2} \mathrm{O}_{3}{ }^{\mathrm{T}}+\mathrm{MgO}$ vs. $\mathrm{TiO}_{2}$. Symbols are arranged according to their sedimentation age (e.g. $\mathrm{S}$ signifies Silurian samples).

A recently published study of selected Neogene sediments deposited in known tectonic environments has shown that six commonly used major element discriminant diagrams have a low percentage success [52], and similar discrepancies have been encountered in an ancient sedimentary basin $[53,54]$. However, other studies have continued to use these discrimination diagrams with apparent success (e.g. Osae et al. [55]; Dokuz and Tanyolu [56]). Most of the Paleozoic sedimentary rocks from the Xing-Meng Orogen are plotted in active environments on major and trace element discriminant diagrams (Figures 7-9), which indicate that a continuous arc-continent accretion process existed during the Ordovician-Silurian. This interpretation is consistent with the environment of sedimentary deposition suggested by the detrital framework mode, and indicates that the final collision time of the Siberia and North China blocks was at the end of the Paleozoic $[22,23,28]$.

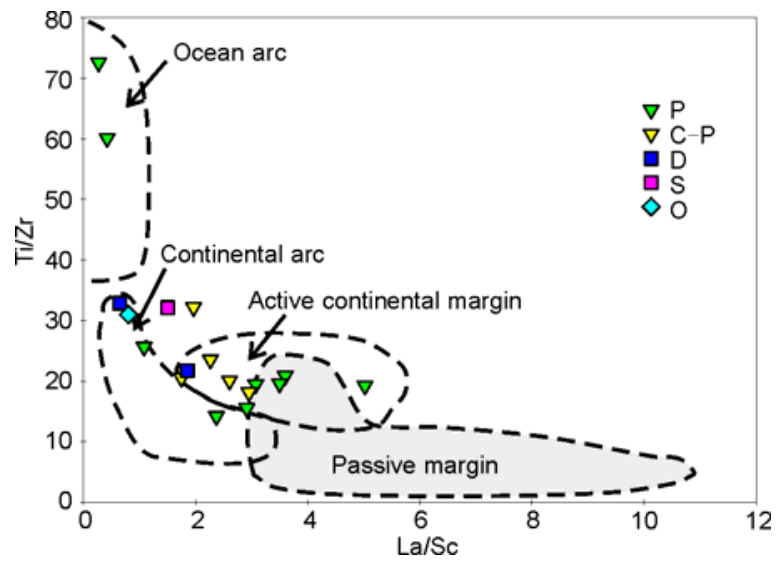

Figure 8 Discrimination diagram of sedimentary environments using the $\mathrm{La} / \mathrm{Sc}$ ratio vs. the $\mathrm{Ti} / \mathrm{Zr}$ ratio for clastic sedimentary rocks in the XingMeng Orogenic Belt [5,57].

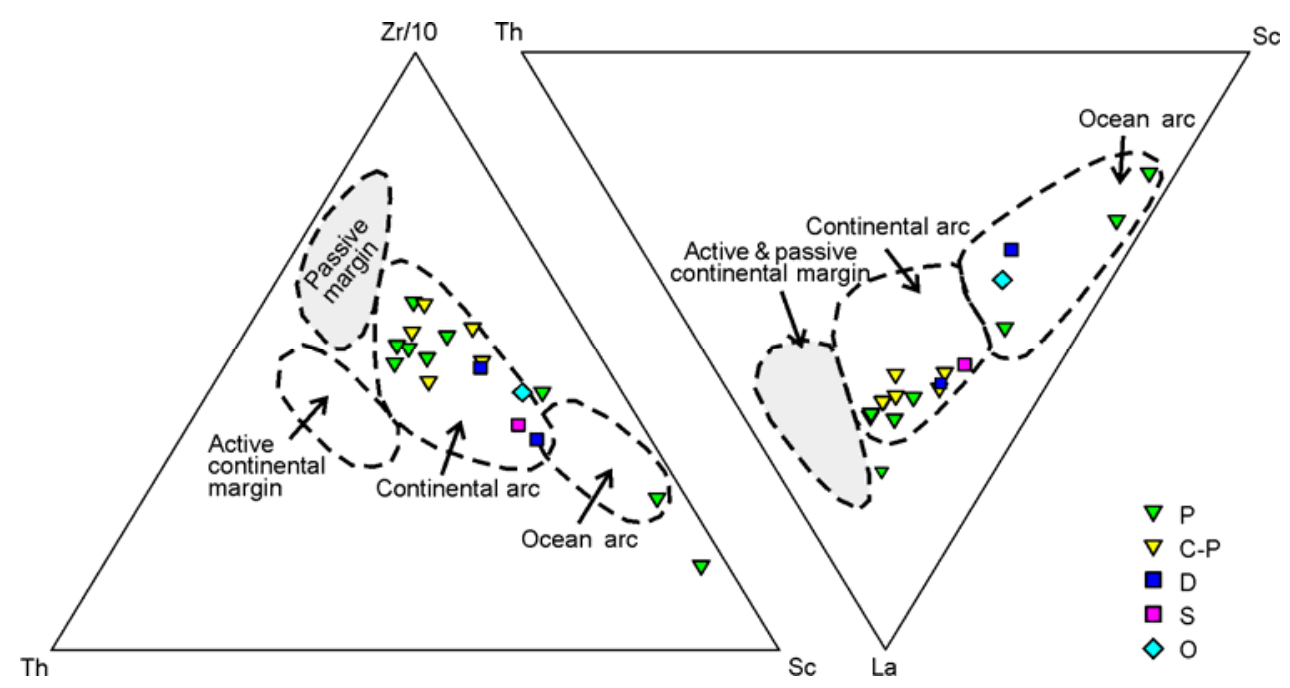

Figure 9 Discrimination diagram of the sedimentary environments using Sc-Th-Zr/10 and Sc-Th-La for clastic sedimentary rocks in the Xing-Meng Orogenic Belt [5]. 


\section{Conclusions}

Provenance characteristics and regional tectonic evolution constraints were obtained from petrography, geochemistry and $\mathrm{Nd}$ isotopes of clastic sedimentary rocks from the Ordovician to Permian in the Xing-Meng Orogenic Belt, eastern to central part of Inner Mongolia. These sedimentary rocks are mainly greywackes and arkosic sandstones, and are characterized by low maturity, poor sorting and a great number of lithic fragments. The provenances of the Paleozoic sandstones mainly are newly accreted crustal materials. Their Nd model ages are distributed mainly in the Neoproterozoic and late Mesoproterozoic and are very different from those of the North China Block. However, the evolution of $\varepsilon_{\mathrm{Nd}}(t)$ in sedimentary rocks is similar to that of igneous rocks in this region, indicating that their provenances are mainly from the Xing-Meng Orogen itself. The clastic sedimentary rocks consist mainly of inputs of juvenile accreted crustal material and a few recycled old crusts. Their provenances are controlled by three end members: a felsic end member, a partially melted mafic end member and a mafic end member. These end members must have had a ratio of 53:41:5 to produce the average compositions of the clastic sedimentary rocks. The depositional environment began to change from an arc to an orogen during the Permian, and therefore the collision was completed before the Triassic. This interpretation is consistent with the argument that the final collision time was at the end of the Permian to Triassic $[22,23,28]$.

Li Dapeng is grateful to Dr. Paul Asimow of the California Institute of Technology for his help with the MELTs algorithm. We also thank Prof. Luo Zhaohua of the China University of Geosciences in Beijing for providing valuable references for this region and Dong Ruchun, for assistance with sedimentary petrography. The authors are indebted to three anonymous reviewers for their suggestions that resulted in substantial improvements to the paper. This work was supported by the National Natural Science Foundation of China (40973010), the Fundamental Research Funds for the Central Universities (2011YYL012) and the Department of Land and Resources, Inner Mongolia Autonomous Region (05-6-YS2).

1 Taylor S R, McLennan S M. The Continental Crust: Its Composition and Evolution. Oxford: Blackwell Scientific Publications, 1985. $1-312$

2 Roser B P, Korsch R J. Provenance signatures of sandstone-mudstone suites determined using discriminant function analysis of majorelement data. Chem Geol, 1988, 67: 119-139

3 McLennan S M, Hemming S R, Taylor S R, et al. Early Proterozoic crustal evolution: Geochemical and $\mathrm{Nd}-\mathrm{Pb}$ isotopic evidence from metasedimentary rocks, southwestern North America. Geochem Cosmchem Acta, 1995, 59: 1153-1177

4 Bhatia M R. Plate tectonics and geochemical composition of sandstones. J Geol, 1983, 91: 611-627

5 Bhatia M R, Crook K A W. Trace element characteristics of graywackes and tectonic setting discrimination of sedimentary basins. Contrib Mineral Petrol, 1986, 92: 181-193

6 Dickinson W R. Interpreting detrtital modes of greywacke and arkose. J Sediment Petrol, 1970, 40: 695-707

7 Dickinson W R, Beard L S, Brakenridge G R, et al. Provenance of North American Phanerozoic sandstones in relation to tectonic setting.
Geol Soc Amer Bull, 1983, 94: 222-235

8 Goldstein S J, Jacobsen S B. Nd and Sr isotopic systematics of river water suspended material: Implications for crustal evolution. Earth Planet Sci Lett, 1988, 87: 249-265

9 Barovich K M, Foden J. A Neoproterozoic flood basalt province in southerncentral Australia: Geochemical and $\mathrm{Nd}$ isotope evidence from basin fill. Precambrian Res, 2000, 100: 213-234

10 McLennan S M, Bock B, Hemming R S, et al. The roles of provenance and sedimentary processes in the geochemistry of sedimentary rocks. In: Lentz D R, ed. Geochemistry of Sediments and Sedimentary Rocks: Evolutionary Considerations to Mineral Deposit-forming Environments. Geol Assoc Can, 2003. 7-38

11 Patchett P J. Provenance and crust-mantle evolution studies based on radiogenic isotopes in sedimentary rocks. In: Lentz D R, ed. Geochemistry of Sediments and Sedimentary Rocks: Evolutionary Considerations to Mineral Deposit-forming Environments. Geol Assoc Can, 2003. 69-77

12 Chen Y L, Li D P, Zhou J, et al. U-Pb ages of zircons in western Qinlingshan, China, and their tectonic implications. Earth Sci Front, 2008, 15: 88-107

13 Chen Y L, Li D P, Zhou J, et al. U-Pb dating, geochemistry, and tectonic implications of the Songpan-Ganzi block and the Longmenshan, China. Geochem J, 2009, 43: 77-99

14 Howard K E, Hand M, Barovich K M, et al. Detrital zircon ages: Improving interpretation via $\mathrm{Nd}$ and $\mathrm{Hf}$ isotopic data. Chem Geol, 2009, 262: 277-292

15 Khain E V, Bibikova E V, Kröner A, et al. The most ancient ophiolite of the Central Asian fold belt: $\mathrm{U}-\mathrm{Pb}$ and $\mathrm{Pb}-\mathrm{Pb}$ zircon ages for the Dunzhugur Complex, Eastern Sayan, Siberia, and geodynamic implications. Earth Planet Sci Lett, 2002, 199: 311-325

16 Zhang Y P, Tang K D. Pre-Jurassic tectonic evolution of intercontinental region and the suture zone between the North China and Siberian platforms. J Southeast Asian Earth Sci, 1989, 3: 47-55

17 Tang K D. Tectonic development of Paleozoic fold belts at the north margin of the Sino-Korean craton. Tectonics, 1990, 9: 249-260

18 Guo S Z. Timing of convergence process of Sino-Korean plate and Siberian plate inferred from biostratigraphic evidences. In: Ishii $\mathrm{K}$, Liu X Y, Ichikawa K, et al., eds. Pre-Jurassic Geology of Inner Mongolia, China, China-Japan Cooperative Group. Osaka: Osaka University, 1991. 113-125

19 Wang Q, Liu X Y. Paleoplate tectonics between Cathaysia and Angaraland in Inner Mongolia of China. Tectonics, 1986, 5: 1073-1088

20 Huang B H. Biogeography of Late Paleozoic Floras of northeastern China. In: Ishii K, Liu X Y, Ichikawa K, eds. Pre-Jurassic Geology of Inner Mongolia, China, China-Japan Cooperative Group. Osaka: Osaka University, 1991. 159-174

21 Nozaka T, Liu Y. Petrology of the Hegenshan ophiolite and its implications for the tectonic evolution of northern China. Earth Planet Sci Lett, 2002, 202: 89-104

22 Xiao W J, Windley B F, Hao J, et al. Accretion leading to collision and the Permian Solonker suture, Inner Mongolia, China: Termination of the Central Asian Orogenic Belt. Tectonics, 2003, 22: 1069_ 1089

23 Xiao W J, Windley B F, Huang B C, et al. End-Permian to mid-Triassic termination of the accretionary processes of the southern Altaids: Implications for the geodynamics evolution, Phanerozoic continental growth, and metallogeny. Int J Earth Sci, 2009, 98: 1189-1217

24 Wu F Y, Zhao G C, Sun D Y, et al. The Hulan Group: Its role in the evolution of the Central Asian Orogenic Belt of NE China. J Asian Earth Sci, 2007, 30: 542-556

25 Shi G H, Liu D Y, Zhang F Q, et al. SHRIMP U-Pb zircon geochronology and its implications on the Xilin Gol Complex, Inner Mongolia, China. Chin Sci Bull, 2003, 48: 2742-2748

26 Chen B, Jahn B M, Tian W. Evolution of the Solonker suture zone: Constraints from zircon $\mathrm{U}-\mathrm{Pb}$ ages, $\mathrm{Hf}$ isotopic ratios and whole-rock $\mathrm{Nd}-\mathrm{Sr}$ isotope compositions of subduction- and collision-related magmas and forearc sediments. J Asian Earth Sci, 2009, 34: 245-257

27 Long X P, Sun M, Yuan C, et al. Detrital zircon age and Hf isotopic studies for metasedimentary rocks from the Chinese Altai: Implica- 
tions for the Early Paleozoic tectonic evolution of the Central Asian Orogenic Belt. Tectonics, 2007, 26: TC5015

28 Li Q L, Chen F K, Guo J H, et al. Zircon ages and Nd-Hf isotopic composition of the Zhaertai Group (Inner Mongolia): Evidence for early Proterozoic evolution of the North China Craton. J Asian Earth Sci, 2007, 30: 573-590

29 Xia X P, Sun M, Zhao G C, et al. U-Pb and Hf isotopic study of detrital zircons from the Wulashan khondalites: Constraints on the evolution of the Ordos Terrane, Western Block of the North China Craton. Earth Planet Sci Lett, 2006, 241: 581-593

30 Li G W, Li Q F, Jiang W D. Multiple classification and correlation of the stratigraphy of China (15): Stratigraphy (Lithostratic) of Nei Mongol Autonomous Region (in Chinese). Wuhan: China University of Geosciences Press, 1996

31 Hu X, Xu C S, Niu S Y. Evolution of the Early Paleozoic Continental Margin in Northern Margin of the North China Platform (in Chinese). Beijing: Peking University Press, 1990

32 Zhao G, Zhu Y F, Zhang Y. Petrology and metamorphic conditions of the Xilinhot metamorphic complex, Inner Mongolia, China (in Chinese). Acta Petrol Mineral, 2002, 21: 40-48

33 Xu B, Charvet J, Zhang F. Primary study on petrology and geochronology of blueschists in Sunitezuoqi, northern Inner Mongolia. J Geol, 2001, 46: 6-14

34 Chen B, Jahn B M, Wilde S, et al. Two contrasting Paleozoic magmatic belts in northern Inner Mongolia, China: Petrogenesis and tectonic implications. Tectonophysics, 2000, 328: 157-182

35 Miao L C, Wang F, Liu D Y, et al. Geochronology and geochemistry of the Hegenshan ophiolitic complex: Implications for late-stage tectonic evolution of the Inner Mongolia-Daxinganling Orogenic Belt, China. J Asian Earth Sci, 2008, 32: 348-370

36 Jahn B M, Cornichet J, Cong B L, et al. Ultrahigh- $\varepsilon_{\mathrm{Nd}}$ eclogites from an ultrahigh-pressure metamorphic terrane of China. Chem Geol, 1996, 127: 61-79

37 Pettijohn F J, Potter P E, Siever R. Sand and Sandstone. New York: Springer-Verlag, 1972. 1-130

38 Rudnick R L, Gao S. Composition of the continental Crust. In: Holland H D, Turnekian K K, eds. The Crust Vol. 3 Treatise on Geochemistry. Oxford: Elsevier-Pergamon, 2003. 1-64

39 Boynton W V. Cosmochemistry of the rare earth elements: Meteorite studieds. In: Henderson P, ed. Rare Earth Element Geochemistry. Amsterdam: Elsevier, 1984. 63-114

40 Wu F Y, Zhao G C, Wilde S A, et al. Nd isotopic constraints on crustal formation in the North China Craton. J Asian Earth Sci, 2005, 24: 523-545

41 Hong D W, Zhang J S, Wang T, et al. Continental crustal growth and the supercontinental cycle: Evidence from the Central Asian Orogenic Belt. J Asian Earth Sci, 2004, 23: 799-813

42 Chen Y L, Liu F, Zhang H F, et al. Elemental and Sm-Nd isotopic geochemistry on detrital sedimentary rocks in the Ganzi-Songpan block and Longmen Mountains. Front Earth Sci, 2007, 1: 60-68

43 Ghiorso M S, Sack R O. Chemical mass-transfer in magmatic processes IV. A revised and internally consistent thermodynamic model for the interpolation and extrapolation of liquid-solid equilibria in magmatic systems at elevated-temperatures and pressures. Contrib Mineral Petrol, 1995, 119: 197-212

44 Asimow P D, Ghiorso M S. Algorithmic modifications extending MELTs to calculate subsolidus phase relations. Amer Mineral, 1998, 83: $1127-1132$

45 Smith P M, Asimow P D. Adiabat_1ph: A new public front-end to the MELTs, pMELTS, and pHMELTS models. Geochem Geophys Geosys, 2004, doi:10.1029/2004GC000816

46 Thompson A B. Some time-space relationships for crustal melting and granitic intrusion at various depths. In: Castro A, Fernández C, Vigneresse J L, eds. Understanding Granites: Integrating New and Classical Tectniques. Geological Society Special Publication, No. 168. London: The Geological Society Publishing House, 1999. 1-7

47 Li D P, Chen Y L, Chen L M, et al. Zircon LA-ICPMS study and petrogenesis simulation of Dahuabei pluton in the Wulashan area, Inner Mongolia. Prog Nat Sci, 2009, 19: 1727-1737

48 Chen Y L, Yang Z F, Zhao Z D. Isotopic Geochronology and Geochemistry (in Chinese). Beijing: Geological Publishing House, 2005. $1-441$

49 Marsaglia K M, Ingersoll R V. Compositional trends in arc-related, deep-marine sand and sandstone: A reassessment of magmatic-arc provenance. Geol Soc Am Bull, 1992, 104: 1637-1649

50 Li D P, Chen Y L, Wang Z, et al. Detrital zircon U-Pb ages, Hf isotopes and tectonic implications for Palaeozoic sedimentary rocks from the Xing-Meng Orogenic Belt, middle-east part of Inner Mongolia, China. Geol J, 2011, 46, doi:10.1002/gj.1257

51 Li R W, Wan Y S, Cheng Z Y, et al. Provenance of Jurassic sediments in the Hefei Basin, East Central China and the contribution of high-pressure and ultrahigh-pressure metamorphic rocks from the Dabie Shan. Earth Planet Sci Lett, 2005, 231: 279-294

52 Armstrong-Altrin J S, Verma S P. Critical evaluation of six tectonic setting discrimination diagrams using geochemical data of Neogene sediments from known tectonic settings. Sediment Geol, 2005, 177: 115-129

53 Van de Kamp P C, Leake B E. Petrography and geochemistry of feldspathic and mafic sediments of the northeastern Pacific margin. Trans R Soc Edinb Earth Sci, 1985, 76: 411-419

54 Shao L, Stattegger K, Carbe-Schoenberg C-D. Sandstone petrology and geochemistry of the Turban Basin (NW China): Implications for the tectonic evolution of a continental basin. J Sediment Res, 2001, 71: 37-49

55 Osae S, Asiedu D K, Banoeng-Yakubo B, et al. Provenance and tectonic setting of Late Proterozoic Buem sandstones of southeastern Ghana: Evidence from geochemistry and detrital modes. J Afr Earth Sci, 2006, 44: 85-96

56 Dokuz A, Tanyolu E. Geochemical constraints on provenance, mineral sorting and subaerial weathering of Lower Jurassic and Upper Cretaceous clastic rocks of the eastern Pontides, Yusufeli (Artvin), NE Turkey. Turk J Earth Sci, 2006, 15: 181-209

57 Bahlburg H. The geochemistry and provenance of Ordovician turbidites in the Argentine Puna. In: Pankhurst R J, Rapela C W, eds. The Proto-Andean margin of Gondwana. Geol Soc Lond Spec Pub, 1998, 127-142

Open Access This article is distributed under the terms of the Creative Commons Attribution License which permits any use, distribution, and reproduction in any medium, provided the original author(s) and source are credited. 